\title{
Substantial understory contribution to the $C$ sink of a European temperate mountain forest landscape
}

\author{
T. Dirnböck (1) - D. Kraus $・$ R. Grote $\cdot$ S. Klatt $\cdot$ J. Kobler $・$ A. Schindlbacher • \\ R. Seidl $\cdot$ D. Thom $\cdot$ R. Kiese
}

Received: 14 March 2019/Accepted: 10 December 2019/Published online: 3 February 2020

(C) The Author(s) 2020

\begin{abstract}
Context The contribution of forest understory to the temperate forest carbon sink is not well known, increasing the uncertainty in $\mathrm{C}$ cycling feedbacks on global climate as estimated by Earth System Models. Objectives We aimed at quantifying the effect of woody and non-woody understory vegetation on net ecosystem production (NEP) for a forested area of $158 \mathrm{~km}^{2}$ in the European Alps.
\end{abstract}

Electronic supplementary material The online version of this article (https://doi.org/10.1007/s10980-019-00960-2) contains supplementary material, which is available to authorized users.

T. Dirnböck · J. Kobler

Department for Ecosystem Research and Environmental Information Management, Environment Agency Austria, Spittelauer Lände 5, 1090 Vienna, Austria

D. Kraus $(\bowtie) \cdot$ R. Grote $\cdot$ S. Klatt $\cdot$ R. Kiese Karlsruhe Institute of Technology, Institute of Meteorology and Climate Research, Atmospheric Environmental Research (IMK-IFU), Kreuzeckbahnstraße 19, 82467 Garmisch-Partenkirchen, Germany e-mail: david.kraus@kit.edu

\section{A. Schindlbacher}

Department of Forest Ecology, Federal Research and Training Centre for Forests, Natural Hazards and Landscape (BFW), Seckendorff-Gudent Weg 8, 1131 Vienna, Austria
Methods We simulated C dynamics for the period 2000-2014, characterized by above-average temperatures, windstorms and a subsequent bark beetle outbreak for the area, using the regional ecosystem model LandscapeDNDC.

Results In the entire study area, woody and nonwoody understory vegetation caused between 16 and $37 \%$ higher regional NEP as compared to a bare soil scenario over the 15-year period. The mean annual contribution of the understory to NEP was in the same order of magnitude as the average annual European (EU-25) forest C sink. After wind and bark beetle disturbances, the understory effect was more pronounced, leading to an increase in NEP between 35

\section{R. Seidl · D. Thom}

Department of Forest- and Soil Sciences, Institute of Silviculture, University of Natural Resources and Life Sciences (BOKU) Vienna, Peter-Jordan Straße 82, 1190 Vienna, Austria

R. Seidl · D. Thom

Ecosystem Dynamics and Forest Management Group, School of Life Sciences, Technical University of Munich, Hans-Carl-von-Carlowitz-Platz 2, 85354 Freising, Germany

D. Thom

Rubenstein School of Environment and Natural Resources, University of Vermont, 81 Carrigan Drive, Burlington, VT 05405, USA 
and $67 \%$ compared to simulations not taking into account these components.

Conclusions Our findings strongly support the importance of processes related to the understory in the context of the climate change mitigation potential of temperate forest ecosystems. The expected increases in stand replacing disturbances due to climate change call for a better representation of understory vegetation dynamics and its effect on the ecosystem $\mathrm{C}$ balance in regional assessments and Earth System Models.

Keywords Net ecosystem production - Carbon sequestration - Mountain forest - Herb layer - Tree regeneration $\cdot$ Forest disturbance $\cdot$ Ecosystem modelling

\section{Introduction}

Earth System Models (ESM) substantially improved our understanding of ecosystem carbon (C) cycling feedbacks on global climate (Flato et al. 2013; Bonan and Doney 2018). Nevertheless, many of the biogeophysical feedbacks remain to be addressed in a better way (Steffen et al. 2018). In forests, among the biggest challenges is the identification of $\mathrm{C}$ dynamics related to the understory including shrubs, herbs, grasses and small trees (Thrippleton et al. 2016; Landuyt et al. 2018). Forest ground vegetation contributes to ecosystem production and litter input, mediating carbon and nutrient dynamics (Nilsson and Wardle 2005; Gilliam 2007). At the same time, tree regeneration in the forest understory and ground vegetation are crucial for swiftly recovering $\mathrm{C}$ stocks after stand replacing forest disturbance (Edburg et al. 2012). However, the magnitude of uncertainty in modelled net ecosystem production (NEP) estimates as a result of disregarded processes mediated by forest understory is still unknown.

Forest stand replacing disturbances are classical examples where the understory determines $\mathrm{C}$ and nutrient dynamics because trees in the mid- and understory can take advantage of elevated light, water and nutrient availability, rapidly increasing photosynthetic activity and growth (Brown et al. 2010; Edburg et al. 2011; Mathys et al. 2013; Williams et al. 2014). However, a number of factors can limit tree regeneration, thereby causing a delay in the recovery of the C sink strength (Mayer et al. 2014; Matthews et al. 2017). Tree regeneration in temperate forests is often limited by browsing of large ungulates (Ammer 1996; Motta 1996; Friedrich Reimoser and Gossow 1996), seed predation by small mammals (Nopp-Mayr et al. 2012), or a scarcity of microsites suitable for germination (Diaci et al. 2005; Kupferschmid and Bugmann 2005). In addition, understory grasses and herbs (ground vegetation) can thwart tree regeneration after disturbance through competition (Ammer 1996; Pröll et al. 2015; Reimoser and Gossow 1996; Turner et al. 1997), with potential negative effects on NEP. At the same time, ground vegetation contributes to forest C sequestration (Nilsson and Wardle 2005; Gilliam 2007). The effect of ground vegetation on $C$ sequestration also increases after tree replacing disturbances. This has been shown for lodgepole pine forests after a mountain pine beetle outbreak in British Colombia, Canada (Bowler et al. 2012), for a clearcut in NorthEastern US mixed conifer-hardwood forest (Williams et al. 2014), for wind throw areas in the High Tatra Mountains, Slovakia (Don et al. 2012), and for disturbed Norway spruce forests of the Kalkalpen National Park, Austria (Zehetgruber et al. 2017).

The above-cited studies substantially improved our knowledge about understory effects on $\mathrm{C}$ dynamics. However, all of them were plot-scale studies, and many were based on eddy flux measurements typically located in topographically flat and homogenous areas (Edburg et al. 2012). The effects of forest understory on NEP can therefore not easily be generalized over large, complex landscapes characterized by variation in site conditions, stand age, disturbance impact, understory plant functional attributes, and the ability of tree species to regenerate (Edburg et al. 2012; Williams et al. 2014). Moreover, disturbances are likely to gain importance as drivers of understory processes affecting NEP in temperate forests of Europe since wind events (Gregow et al. 2017) and bark beetle outbreaks are predicted to increase under climate change (Seidl and Rammer 2017; Seidl et al. 2014).

This paper presents, to our knowledge, the first landscape-scale study quantifying the effects of tree regeneration and ground vegetation development on temperate forest NEP using the ecosystem model system LandscapeDNDC (Grote et al. 2009; Haas et al. 2013) that includes process-based submodels for 
the simulation of forest carbon, nitrogen, and water cycles. Various sources of information such as airborne images, long-term field and LiDAR data were used to initialize and calibrate the model. We applied LandscapeDNDC on an area of $158 \mathrm{~km}^{2}$ at Kalkalpen National Park, Austria, a complex mountain region where disturbances have altered forest structure and function in the recent past and are expected to increase in the coming decades driven by climate change (Thom et al. 2017b). We focused our analysis on a 15 year time period (2000 to 2014), characterized by the three warmest years $(2005,2010$, 2014) in 165-year global instrumental records (WMO 2015), an extreme heat wave in 2003 (Ciais et al. 2005), and high disturbance activity.

We hypothesized that forest understory increased the regional NEP through higher net primary production (NPP) and C input to the soil. We expected a higher NEP of the landscape after disturbance by including both, tree regeneration (Brown et al. 2010; Edburg et al. 2011; Mathys et al. 2013; Williams et al. 2014) as well as growth of ground vegetation (Bowler et al. 2012; Don et al. 2012; Williams et al. 2014; Zehetgruber et al. 2017) in the simulations. We also hypothesized that understory growth of trees and ground vegetation do not result in simple additive effects on NEP but that ground vegetation supresses $\mathrm{C}$ uptake of tree regeneration, particularly shortly after disturbance events (Ammer 1996; Reimoser and Gossow 1996; Pröll et al. 2015; Thrippleton et al. 2016).

\section{Materials and methods}

Study area

The Kalkalpen National Park is located at $\mathrm{N} 47.47^{\circ} \mathrm{E} 14.22^{\circ}$ in the Northern Limestone Alps of Austria. The complex mountainous landscape, with elevations ranging from 385 to $1963 \mathrm{~m}$ a.s.l., is mostly forested $(81 \%)$. Mean annual temperature ranges between 3.6 and $9.0{ }^{\circ} \mathrm{C}$ and annual precipitation between 1205 and $1741 \mathrm{~mm}$ (Thom et al. 2017b). Soils are predominantly shallow with Lithic and Rendzic Leptosols and Chromic Cambisols as the dominant soil types over carbonate bedrock. In our study, we focussed on all forested areas $<1200 \mathrm{~m}$ a.s.l. covering $158 \mathrm{~km}^{2}$ dominated by montane
European beech (Fagus sylvatica (L.)) and mixed spruce (Picea abies (L. Karst.))—silver fir (Abies alba (Mill.))_beech forest types. The investigated time period between 2000 and 2014 included disturbance events triggered by the storms Kyrill, Paula and Emma, which hit Central Europe in the years 2007 and 2008. A subsequent bark beetle outbreak-fanned by the storm events-lasted from 2007 to 2012 (Seidl and Rammer 2017).

\section{LandscapeDNDC model description}

To estimate growth of over- and understory trees as well as ground vegetation, and to distinguish between soil and plant respiration, we applied the ecosystem model system LandscapeDNDC (Grote et al. 2009; Haas et al. 2013). LandscapeDNDC has been used to determine forest development under undisturbed (Grote et al. 2011; Molina-Herrera et al. 2015) as well as disturbed conditions (Lindauer et al. 2014) and to estimate associated emissions of atmospheric trace gases (Kraus et al. 2015; Molina-Herrera et al. 2015) as well as leaching losses (Kiese et al. 2011; Dirnböck et al. 2016). Regional LandscapeDNDC applications are grid-based assuming that each simulated grid cell is an independent homogenous simulation unit representing a defined plant-soil system without lateral exchange of water, energy and matter. Within LandscapeDNDC, core models are $\operatorname{MeTr}^{\mathrm{x}}$ (Kraus et al. 2015) and PSIM-Physiological Simulation Model (Grote 2007) describing soil biogeochemical and vegetation processes, respectively. The following paragraphs briefly describe the most important concepts and model adaptions regarding vegetation and hydrology that are relevant for this study.

\section{Cohort approach}

PSIM characterizes the vegetation in a grid cell in form of homogeneously distributed cohorts, i.e., groups of uniform morphology that represent different species or different dimensions (e.g. trees of different social classes) as well as ground covering species such as grasses and herbs (Grote et al. 2011). The vegetation within one simulation unit can thus be represented by multiple coexisting cohorts. The number of cohorts needs to be initialized and is constant during the simulation. This also means that cohorts are not merged even if they would develop into similar 
dimensions (for details see section model input). Biomass development of all cohorts (mature overstory trees, understory trees, and ground vegetation) is basically described by the same processes, which are photosynthesis and phenology, respiration, allocation and senescence (see Grote et al. 2009 and references therein), considering in principal the same plant organs (wood, foliage, fine roots, reserves, etc.).

\section{Dimensional growth}

For tree cohorts (over- and understory), structural growth (height, stem and crown diameter, etc.) is calculated for an average representative tree based on the biomass changes of the woody compartment using the allometric relationships presented by (Bossel 1996; Grote et al. 2011). The allocation into woody tissue is calculated based on the pipe-model theory (Shinozaki and Yoda 1964) that assumes a speciesspecific ratio between sapwood area and foliage and is driven by phenological development (Grote 2007). Because this ratio is set to zero for ground vegetation, no wood formation (and thus no woody biomass and no structural growth) is computed for grass and herbaceous ground vegetation cohorts.

For tree cohorts, area coverage directly results from crown dimensions and number of individuals. Due to missing structural growth of ground vegetation cohorts, an empirical function was developed that dynamically scales the area coverage of ground vegetation $\left(A_{h}\right)$ depending on overstory tree coverage $\left(A_{o}\right)$, using the findings of Helm et al. (2017). This function was based on 54 permanent forest plots $(10 \times 10 \mathrm{~m})$, presenting a robust relationship of $\mathrm{A}_{\mathrm{o}}$ and $A_{h}$ for the study region (see details in $\mathrm{S} 2$ ).

\section{Linking dimensional growth and foliage biomass}

Dimensional growth of cohorts determines the upper limit of newly formed leaves from stored material at budburst. This cohort-specific value is given as a parameter for a closed canopy and restricted by crown volume for tree species cohorts and area coverage for ground vegetation cohorts.

\section{Biomass distribution}

Each cohort has its biomass distributed within the canopy space that is differentiated into layers of equal height. The distribution of leaf biomass over the length of the crown is modelled with a distribution function based on a species-specific parameter and crown length as a variable (Grote 2003, 2007). In case of ground vegetation, leaf biomass is completely allocated to the first canopy layer above ground due to missing structural growth. Leaf area per canopy layer is afterwards determined from biomass and specific leaf area. For trees, specific leaf area develops linearly from a minimum at the treetop to a maximum at crown base, while specific leaf area is set constant for grass and herbaceous ground vegetation.

\section{Competition}

Micrometeorological-, water- and nitrogen balance calculations determine climatic conditions and resource availability in each of these layers that affect-but are also influenced by-the cohort's properties and interactions. Thus, all cohorts are in competition with each other. For example, light availability and thus photosynthesis in one canopy layer depends on the amount and properties of the foliage in higher layers. Belowground, soil water and nitrogen in a layer is only accessible for a plant cohort when sufficient fine roots are present.

\section{Hydrology}

In addition to model adaptations regarding area cover of ground vegetation, the tipping bucket approach of vertical soil water movement (Kiese et al. 2011) is replaced by a Van Genuchten approach to describe water percolation more realistically. The adaptation of the soil hydrology descriptions (details are provided in S1) was motivated by numerical problems of the tipping bucket approach for the simulation of soils with high stone contents, which are widespread in the study region.

\section{Simulation design}

The study region was discretized by a regular $100 \times 100 \mathrm{~m}$ grid resulting in a total of 15,793 simulation units. The vertical discretization of the soil and canopy domain was grid cell specific depending on vegetation and soil characteristics available from surveys. The height of the canopy domain is dynamically calculated depending on the maximum height of 
prevalent vegetation cohorts. A maximum of 40 equally sized layers is used for the canopy discretization. The vertical resolution of the soil domain depends on total soil depth but generally $0.5 \mathrm{~cm}$ layers were set for upper soil (O and A horizons) and $10 \mathrm{~cm}$ layer dimension for lower soil (B horizon). Hourly simulations spanned 15 years covering the time period 2000-2014. In order to explore the potential effect of forest ground vegetation and tree regeneration on ecosystem NEP, four hypothetical scenarios were set up (Table 1).

Model input

\section{Vegetation}

The initialization of the vegetation was based on Thom et al. (2017b), who compiled a wall-to-wall estimate of vegetation structure and composition from forest inventory and planning data, aerial image analysis, and LiDAR data with a spatial resolution of $10 \times 10 \mathrm{~m}$. We aggregated this data to a spatial resolution of $100 \times 100 \mathrm{~m}$ (Table 2; see details in S2). The maximum number of simulated vegetation cohorts per grid cell was set to seven, one cohort representing ground vegetation (only for the $\mathrm{HR}$ and $\mathrm{H}$ scenario), two cohorts representing tree regeneration (only for the HR and R scenario), and four cohorts representing overstory trees (see details in S2). The overstory cohorts represent the two most dominant tree species (depending on aboveground biomass shares) in the two most dominant height classes per grid cell. In the HR and R scenario, two tree regeneration cohorts (tree saplings of the type of the

Table 1 Model scenarios including (+) or excluding (-) forest ground vegetation (i.e. herbs and grasses) and/or tree regeneration

\begin{tabular}{lll}
\hline Scenario name & Ground vegetation & Tree regeneration $^{\mathrm{a}}$ \\
\hline $\mathrm{HR}^{\mathrm{a}}$ & + & + \\
$\mathrm{H}$ & + & - \\
$\mathrm{R}^{\mathrm{a}}$ & - & + \\
$\mathrm{NN}$ & - & -
\end{tabular}

${ }^{\mathrm{a}}$ Note that in addition to the four scenarios, tree regeneration was initialized assuming different densities (500 to 3000 trees $h^{-1}$ ), thereafter indicated as $R_{500}, H_{500}, R_{1000}$, $\mathrm{HR}_{1000}$, etc. respective overstory) were included in all grid cells at the beginning of the simulation. Since LandscapeDNDC doesn't provide a dynamic regeneration module and also because much regeneration is carried out or supported by management, new trees had to be initialized specifically. A total of 2500 tree saplings (height $=0.5 \mathrm{~m}$ ) were initialized because it is the recommended density for sustainable tree regeneration according to regional forestry guidelines (Jasser and Diwold 2014). We considered a proportional partitioning of tree species into the two regrowth cohorts according to the biomass of the respective tree species in the overstory. In reality, however, a lower density is often realized, so that we varied the tree sapling density across simulations from 500 to $3000 \mathrm{ha}^{-1}$ (500, 1000, 1500, 2000, 2500, and 3000). The respective scenarios were indicated as $R_{500}$, $\mathrm{HR}_{500}, \mathrm{R}_{1000}, \mathrm{HR}_{1000}$, etc. Note, that browsing damage to tree saplings by large ungulates was not modelled.

Disturbance effects on vegetation were taken from a previous study carried out in the area (Thom et al. 2017b). This data contained spatially explicit yearly information on disturbed tree volume and disturbance type. The data resolution of $10 \times 10 \mathrm{~m}$ was additively scaled to the $100 \times 100 \mathrm{~m}$ grid size to fit LandscapeDNDC simulations (see details in S2).

\section{Soils}

LandscapeDNDC requires soil-depth-specific initial information of major soil properties, i.e., organic carbon and nitrogen contents, bulk density, $\mathrm{pH}$, texture and soil hydrologic parameters. This information was derived based on soil map data from Kobler (2004), which was available on a spatial resolution of $100 \times 100 \mathrm{~m}$ (see details in S2) (Table 2).

\section{Weather and atmospheric properties}

We used daily weather data from Thom et al. (2017b). Nitrogen deposition was represented by a mean nitrogen concentration in precipitation $\left(2.87 \mathrm{mg}^{-1}\right.$ N) taken from Dirnböck et al. (2016). Atmospheric concentration of $\mathrm{CO}_{2}$ was set constant to $370 \mathrm{ppm}$.

Model parametrization and evaluation

Parametrization for spruces and ground vegetation has been documented in Lindauer et al. (2014). Additional 
Table 2 Initial stem volume (vol), C pool quantities of aboveground stem wood (st), branch wood (br) + foliage biomass (fl), roots (C below), and soil organic carbon stocks (SOC)

\begin{tabular}{lllll}
\hline & \multicolumn{1}{l}{ Overstory } & \multicolumn{2}{l}{ Tree regeneration } & \\
\hline
\end{tabular}

Values correspond to the mean and standard deviation across the complete study region

${ }^{\mathrm{a}} 2500$ tree individuals $\mathrm{ha}^{-1}$

parameters for beech have been obtained from various sources and evaluated e.g. in Grote et al. (2011). Calibration of few allometric parameters for the current study region has already been carried out in a previous study with LandscapeDNDC (Dirnböck et al. 2016). Some minor adjustments, such as the desired height:diameter ratio were set from site measurements to account for the differences between slope and plateau. For evaluation, we used several data sets with observations from the LTER Zöbelboden site (https:// deims.org/8eda49e9-1f4e-4f3e-b58e-e0bb25dc32a6), which is a 90 ha long-term ecosystem research area in the Kalkalpen National Park. The local forest types are representative for the bulk of montane forests in the park (Jost et al. 2011; Kobler et al. 2015; Dirnböck et al. 2016; Zehetgruber et al. 2017). Data from two long-term monitoring plots were used for the calibration of tree growth (IP1: 1996-2010 and IP2: 1998-2016), and soil respiration (IP1: 2009-2011; IP2: 2015) (see details in S3). IP1 is located on a flat plateau (950 $\mathrm{m}$ a.s.l.) stocked by a 115 -year-old spruce-beech forest and Chromic Cambisols and Hydromorphic Stagnosols as the main soil types. IP2 is located adjacent to IP1 on a $36^{\circ}$ steep slope, dominated by an old growth, mixed beech-maple-ash-spruce forest on shallow Lithic and Rendzic Leptosols. Both plots experienced wind and bark beetle disturbances to varying degrees (Kobler et al. 2015). For the comparison of measured versus modelled tree growth, soil moisture, and soil respiration, we used the $\mathrm{R}$ package hydroGOF version 0.3-10 (Zambrano-Bigiarini 2017). Mean error, Pearson correlation coefficient and the Kling-Gupta efficiency (Gupta et al. 2009) were used as indicators to evaluate model performance. The King-Gupta efficiency is an aggregated measure expressing correlation, variability and bias concerning the comparison of modelled simulations with empirical data. Long-term $10 \times 10 \mathrm{~m}(\mathrm{n}=54 ; 1993-2014)$ records of forest vegetation (Helm et al. 2017) were used for the function that scales the ground coverage of ground vegetation depending on overstory tree coverage. Vegetation records at IP1 and IP2 were used for validation of ground vegetation biomass dynamics (see details in S3).

Data analyses

While the amount of $\mathrm{C}$ fixed by photosynthesis in an ecosystem is defined as gross primary production (GPP) and NPP results from GPP minus autotrophic respiration, we defined NEP as GPP minus total ecosystem respiration (the sum of autotrophic and heterotrophic respiration) according to Lovett et al. (2006). Cumulative regional NEP was calculated as the sum of all simulated grid cells over the period 2000 to 2014. Tree regeneration as well as ground vegetation effects on NEP were calculated by subtracting the respective scenarios from each other. For the calculation of understory effects after disturbance, we differentiated between undisturbed areas and areas with $>211 \mathrm{~m}^{3} \mathrm{ha}^{-1}$ stem wood damage, representing $1 \%$ of the total study area, and overstory tree replacement for the average forest stand of the study area (Table 2).

\section{Results}

Model evaluation

Predicted tree stem biomass and soil respiration was well in accordance with observations at the two 
intensively studied plots IP1 and IP2 (S3). Stem biomass development between 1996 and 2010 (IP1) and between 1998 and 2016 (IP2) of the two dominant tree species could be modelled with a Pearson $r>0.99$ and Kling-Gupta efficiency between 0.57 and 0.97 . The model underestimated stem biomass (of Picea abies and Fagus sylvatica) with a mean error of $1 \%$ (IP1) and 33\% (IP2) (Table 3). Note, that the degree of error in IP2 resulted from the difficulty to simulate the heterogeneous tree structure of the stand on the steep slope and does not reflect annual growth estimates in the same way, indicated by the high Pearson correlation coefficients. Daily soil respiration was modelled with a Pearson $r=0.97$ and Kling-Gupta efficiency of 0.93 at IP1, whereas at IP2 Pearson $r$ was 0.66 and Kling-Gupta efficiency was 0.36 . At IP1, the model underestimated soil respiration with a mean error of $4.3 \%$ (IP1), and overestimated soil respiration with a mean error of $15.2 \%$ at IP2 (Table 3). Seasonal peak ground vegetation biomass as modelled with LandscapeDNDC corresponded well with measured biomass (S3) records at IP1 and IP2 showing deviations between 0.01 and $0.05 \mathrm{tha}^{-1}$, representing $1.3 \%$ and $8.3 \%$, respectively (Table 4 ).

\section{Cumulated net ecosystem production (NEP)}

In the $\mathrm{HR}_{2500}$ scenario, the mean $\mathrm{C}$ sink of the study region was $48.3 \pm 20.8 \mathrm{t} \mathrm{C}^{-1}$ between 2000 and 2014 resulting in a total area cumulated NEP of $754 \mathrm{kt}$ $\mathrm{C}$ (Figs. 1, 2a). The NN scenario resulted in a mean NEP of $36.5 \pm 25.1 \mathrm{t} \mathrm{C} \mathrm{ha}^{-1}$ adding up to a total of
Table 4 Estimated and modelled summer season (June to August) ground vegetation biomass for the plateau (IP1) and slope plot (IP2)

\begin{tabular}{cll}
\hline \multirow{2}{*}{ Year } & \multicolumn{2}{l}{ Ground vegetation biomass $\left[\mathrm{t} \mathrm{ha}^{-1}\right]$} \\
\cline { 2 - 3 } & Estimated (mean) & Modelled (mean $\pm \mathrm{SD})$ \\
\hline IP1 & & \\
2004 & 0.66 & $0.64 \pm 0.10$ \\
2007 & 0.69 & $0.71 \pm 0.11$ \\
2010 & 0.77 & $0.78 \pm 0.12$ \\
IP2 & & $0.55 \pm 0.04$ \\
2004 & 0.60 & \\
\hline
\end{tabular}

See S3 for the methods applied to estimate biomass

$570 \mathrm{kt} \mathrm{C}$ for the landscape (Fig. 1). Hence, NEP increased by $32 \%\left(11.8 \pm 12.6 \mathrm{t} \mathrm{C} \mathrm{ha}^{-1}\right)$ when taking tree regeneration and the ground vegetation layer into account (Figs. 1, 2b). The sensitivity analysis with different tree regeneration densities resulted in a $16 \%\left(\mathrm{HR}_{500}\right)$ to $37 \%\left(\mathrm{HR}_{3000}\right)$ NEP increase (Fig. 1).

When accounting for tree regeneration without growth of ground vegetation, i.e. the $\mathrm{R}_{2500}$ scenario, mean NEP resulted in $44.3 \pm 22.6 \mathrm{t} \mathrm{C} \mathrm{ha}^{-1}$ between 2000 and 2014 summing to an area cumulated NEP of 692 kt C (Fig. 1). Hence, NEP increased by $21 \%$ when taking tree regeneration into account. The sensitivity analysis resulted in a $6 \%\left(\mathrm{R}_{500}\right)$ to $26 \%\left(\mathrm{R}_{3000}\right) \mathrm{NEP}$ increase (Fig. 1).

When accounting for only ground vegetation, i.e. the $\mathrm{H}$ scenario, mean NEP resulted in a $40.3 \pm 22 \mathrm{t} \mathrm{C}$

Table 3 Correspondence of modelled and measured stem biomass and soil respiration for the two intensive plots (IP1 and IP2)

\begin{tabular}{llll}
\hline & \multicolumn{2}{l}{ Stem biomass $\left(\mathrm{kg} \mathrm{m}^{-2}\right)$} & \multicolumn{2}{c}{${\text { Soil respiration }\left(\mathrm{kg} \mathrm{C} \mathrm{ha}^{-1} \mathrm{day}^{-1}\right)}^{$\cline { 2 - 3 }$}$} & PIAB & FASY \\
\hline IP1 & $1996-2010$ & $2009-2011$ \\
Mean error & -0.18 & -0.12 & -0.93 \\
Pearson correlation coefficient & 0.99 & 1 & 0.97 \\
Kling-Gupta efficiency & 0.97 & 0.89 & 0.93 \\
IP2 & $1998-2016$ & & 2015 \\
Mean error & -0.24 & -3.22 & 4.58 \\
Pearson correlation coefficient & 0.99 & 0.99 & 0.66 \\
Kling-Gupta efficiency & 0.71 & 0.57 & 0.36 \\
\hline
\end{tabular}

See S3 for details about observation data

PIAB: Norway spruce (Picea abies (L.) H. Karst.); FASY: European beech (Fagus sylvatica L.) 


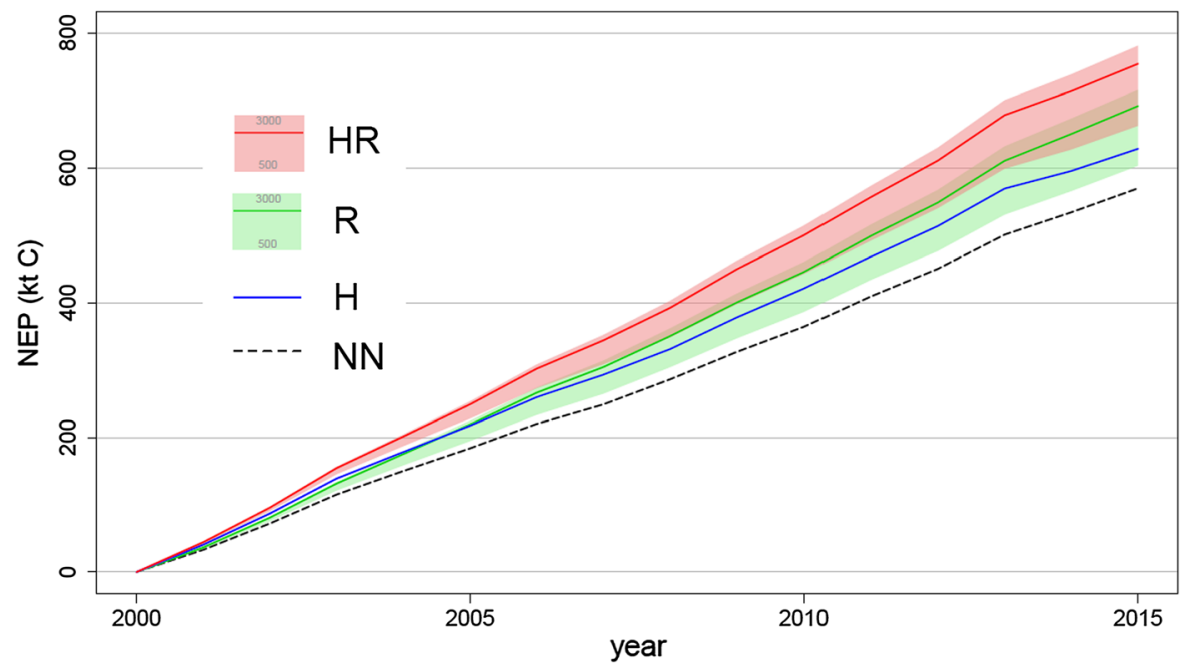

Fig. 1 Cumulative net ecosystem production (NEP) of the study area for the four different scenarios. $N N$ no ground vegetation or tree regeneration, $R$ no ground vegetation but tree regeneration, $H$ ground vegetation but no tree regeneration, $H R$ ground vegetation and tree regeneration. Light green and light

$\mathrm{ha}^{-1}$ sink for atmospheric carbon between 2000 and 2014 resulting in a cumulated NEP of $628 \mathrm{kt} \mathrm{C}$ of the landscape (Fig. 1). This represents a $10 \%$ higher NEP owing to ground vegetation.

The contribution of tree regeneration and ground vegetation to NEP varied across the landscape (Fig. 2b). On $25 \%$ of the area, the $\mathrm{HR}_{2500}$ scenario resulted in a decrease of the cumulated NEP compared to the $\mathrm{NN}$ scenario (mean of negative values: $2.1 \pm 1.7 \mathrm{t} \mathrm{C} \mathrm{ha}^{-1}$ ). In $3 \%$ of the area, the $\mathrm{HR}_{2500}$ scenario resulted in a decrease of the cumulated NEP compared to the $\mathrm{H}$ scenario (mean of negative values: $\left.0.7 \pm 1.2 \mathrm{t} \mathrm{C} \mathrm{ha}^{-1}\right)$.

Mean annual GPP, NPP, total ecosystem respiration (TER), and annual increments in soil organic C (SOC) increased in the order $\mathrm{NN}<\mathrm{R}_{2500}<\mathrm{H}<\mathrm{HR}_{2500}$ scenario (Fig. 3). Mean annual NEP was lowest in the NN scenario $\left(2.4 \pm 1.7 \mathrm{t} \mathrm{C} \mathrm{ha}^{-1}\right.$ year $\left.^{-1}\right)$ and highest in the $\mathrm{HR}_{2500}$ scenario $(3.2 \pm 1.4 \mathrm{t} \mathrm{C}$ $\mathrm{ha}^{-1} \mathrm{y}^{-1}$ ), but the $\mathrm{R}_{2500}$ scenario showed higher values $\left(3.0 \pm 1.5 \mathrm{t} \mathrm{C} \mathrm{ha}^{-1}\right.$ year $\left.^{-1}\right)$ than the $\mathrm{H}$ scenario $\left(2.7 \pm 1.5 \mathrm{t} \mathrm{C} \mathrm{ha}^{-1}\right.$ year $\left.^{-1}\right)$. The latter was due to high TER rates in the $\mathrm{H}$ scenario (Fig. 3) resulting in a lower mean NPP:GPP ratio for the H scenario (0.43) than the $R_{2500}$ scenario (0.47). The contribution of SOC to NEP, indicated by ratios of annual SOC changes and NEP increased in the order $\mathrm{NN}$ red shades show the $R_{500}$ and $R_{3000}$, and $H R_{500}$ and $H R_{500}$ scenario, respectively (subscripts indicate 500 and 3000 trees $\mathrm{ha}^{-1}$ regeneration). Solid lines represent 2500 trees $\mathrm{ha}^{-1}$ regeneration

$(0.12)<\mathrm{HR}_{2500} \quad(0.14)<\mathrm{R}_{2500} \quad(0.18)<\mathrm{H}$

Mean annual NEP of the $R_{500}$ to $R_{3000}$ scenarios was lower than mean annual NEP of the $\mathrm{H}$ scenario only when less than 1000 tree saplings ha $^{-1}$ were used.

Understory effects on NEP after disturbance

In the NN scenario, i.e. without considering tree regeneration and ground vegetation, NEP was higher in undisturbed areas $\left(2.49 \pm 1.73 \mathrm{t} \mathrm{C} \mathrm{ha}^{-1}\right.$ year $\left.^{-1}\right)$ than in disturbed areas $\left(2.30 \pm 1.67 \mathrm{t} \mathrm{C} \mathrm{ha}^{-1}\right.$ year $\left.^{-1}\right)$ during the entire study period (2000 to 2014). With forest disturbance starting in the year 2005 and disturbance impact on growing stock peaking between 2010 and 2012 (Fig. 4a), NEP diverged more strongly between undisturbed and disturbed sites (Fig. 4b). After the year 2007, NEP in disturbed areas was on average $0.59 \mathrm{t} \mathrm{C} \mathrm{ha}^{-1}$ year $^{-1}$ lower than NEP in undisturbed areas (NN scenario).

By evaluating joint effects of tree regeneration and ground vegetation at disturbed sites, we found that mean annual NEP was higher in the $\mathrm{HR}\left(\mathrm{HR}_{500}\right.$ : $0.81 \pm 0.31 ; \quad \mathrm{HR}_{2500}: 1.18 \pm 0.35 ; \quad \mathrm{HR}_{3000}$ : $1.53 \pm 0.37 \mathrm{t} \mathrm{C} \mathrm{ha}^{-1}$ year $^{-1}$ ) compared to the $\mathrm{NN}$ scenario (Fig. 5a). These effects were smaller in undisturbed sites $\left(\mathrm{HR}_{500}: 0.37 \pm 0.26 ; \mathrm{HR}_{2500}\right.$ : $0.73 \pm 0.24 ; \mathrm{HR}_{3000}: 0.82 \pm 0.24 \mathrm{t} \mathrm{C} \mathrm{ha}^{-1}$ year $^{-1}$ ) 

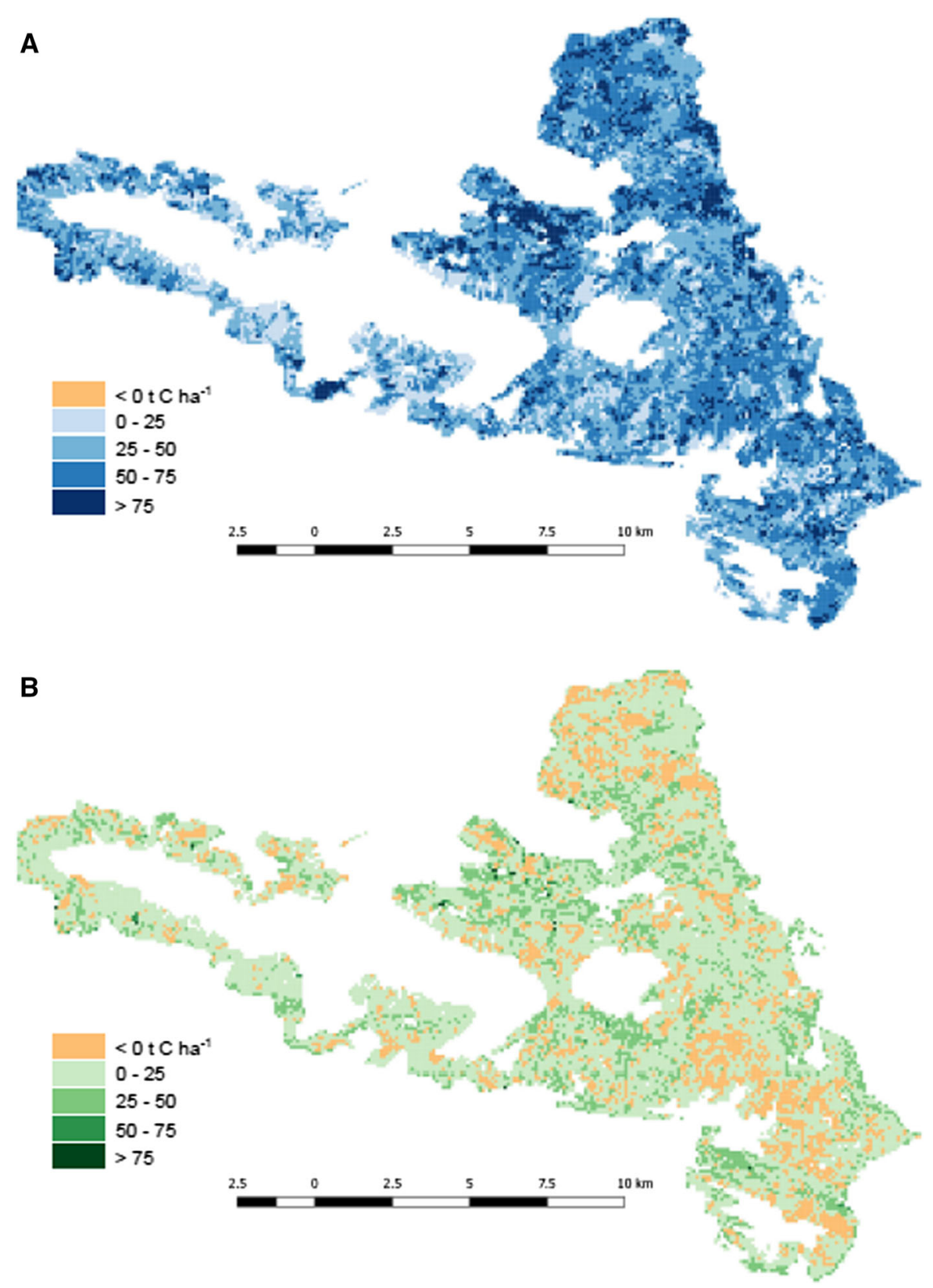

Fig. 2 Cumulative net ecosystem production (NEP) from 2000 to 2014, A without tree regeneration and ground vegetation (NN scenario), and $\mathbf{B}$ effect of tree regeneration and ground vegetation on NEP. Positive values in $\mathbf{A}$ indicate net $\mathrm{C}$ sinks, negative values indicate net $\mathrm{C}$ sources (not visible due to its

(Fig. 5b). Compared to NN, the combined contributions of tree regeneration and ground vegetation caused a 35 and $67 \%$ higher mean annual NEP for $\mathrm{HR}_{500}$ and $\mathrm{HR}_{3000}$ in disturbed areas while only 15 to $33 \%$ for $\mathrm{HR}_{500}$ and $\mathrm{HR}_{3000}$ in undisturbed areas. small extent). Positive values in $\mathbf{B}$ indicate higher NEP when accounting for tree regeneration and ground vegetation, negative values indicate lower NEP (in the range of $2.1 \pm 1.7 \mathrm{t} \mathrm{C} \mathrm{ha}^{-1}$ ). White area is outside the study region. Understory effect was calculated by $\mathrm{HR}_{2500}-\mathrm{NN}$

This difference was mainly driven by the accelerated growth of ground vegetation and annual litter input to the soil. Ground vegetation contributed $4.21 \pm 1.13$ and $2.7 \pm 0.53 \mathrm{t} \mathrm{C} \mathrm{ha}^{-1}$ year $^{-1}$ to mean annual GPP in disturbed and undisturbed areas, 


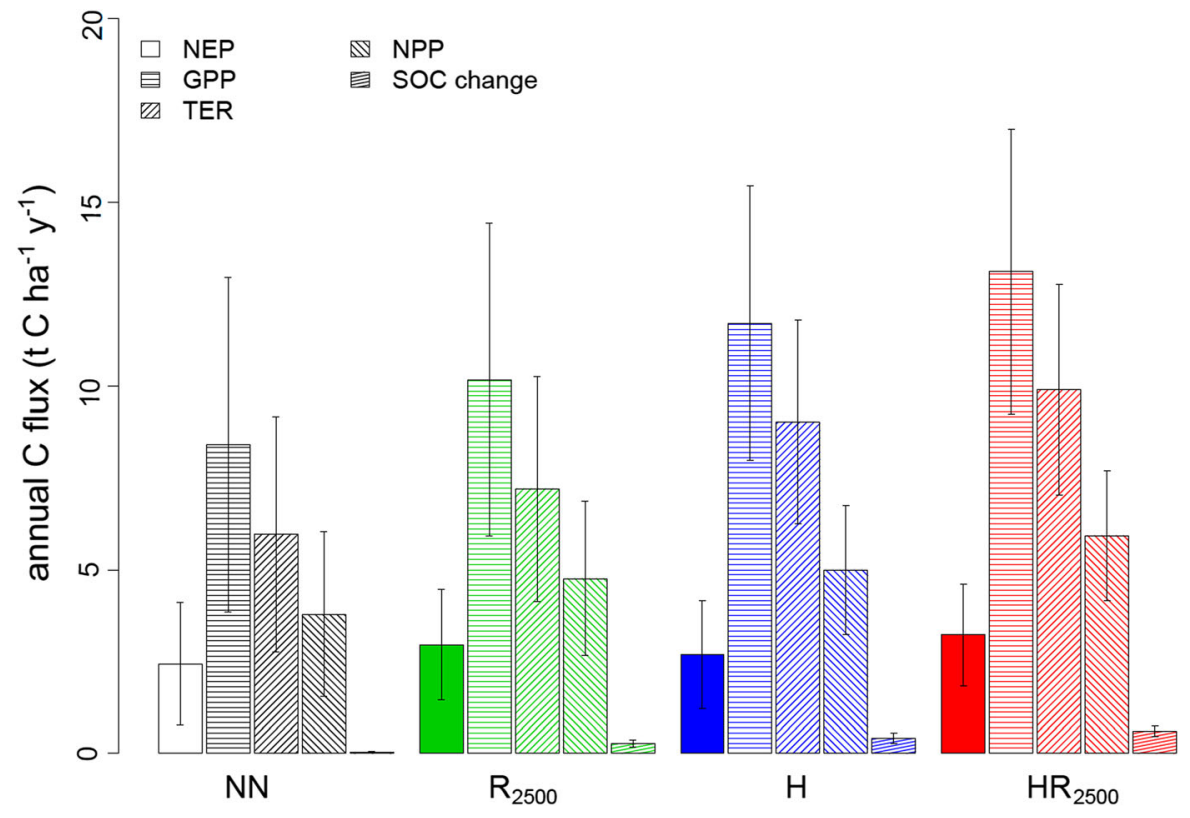

Fig. 3 Magnitude (mean \pm SD) of annual net ecosystem production (NEP), gross primary production (GPP), total ecosystem respiration (TER), net primary production (NPP), and changes in soil organic $\mathrm{C}$ (SOC) in the four scenarios. $N N$ no

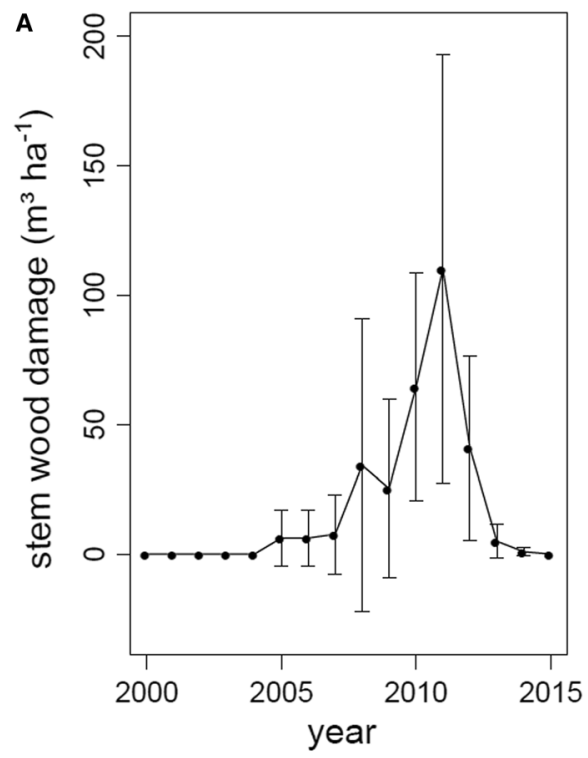

Fig. 4 A Mean annual stem wood damage in disturbed areas of the Kalkalpen National Park ( $1 \%$ of the area with stem wood damage $>211 \mathrm{~m}^{3} \mathrm{ha}^{-1}$ between 2005 and 2014) and $\mathbf{B}$ annual

respectively. In contrast, the difference in the contribution of the tree regeneration to mean annual GPP in disturbed and undisturbed areas was much lower herb layer or tree regeneration, $R_{2500}$ no herb layer but tree regeneration, $H$ herb layer but no tree regeneration, $H R_{2500}$ herb layer and tree regeneration

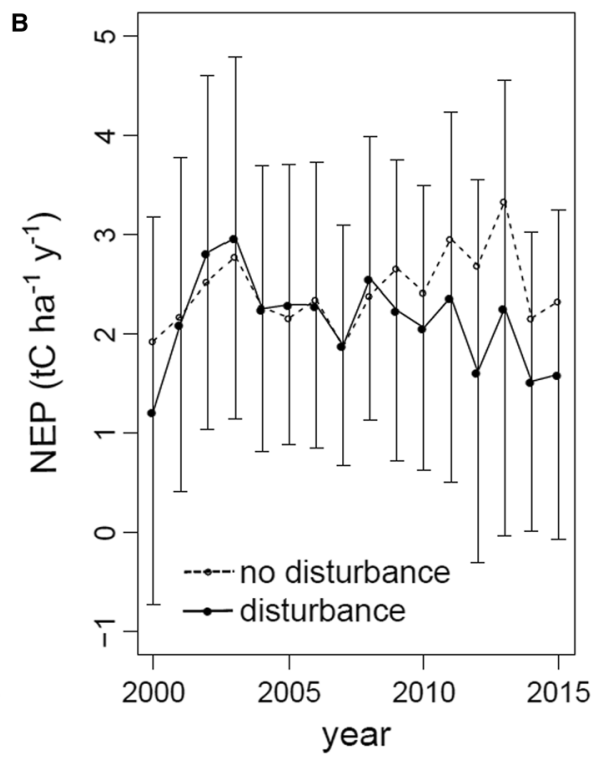

net ecosystem production (NEP) in disturbed (mean \pm SD) and undisturbed (mean) areas in the $\mathrm{NN}$ scenario (i.e. without considering tree regeneration and ground vegetation)

(disturbed areas: $1.43 \pm 0.47 \mathrm{t} \mathrm{C} \mathrm{ha}^{-1}$ year $^{-1}$; undisturbed areas: $1.31 \pm 0.52 \mathrm{t} \mathrm{C} \mathrm{ha}^{-1}$ year $^{-1}$ ). Since the effect of forest ground vegetation on TER did not 


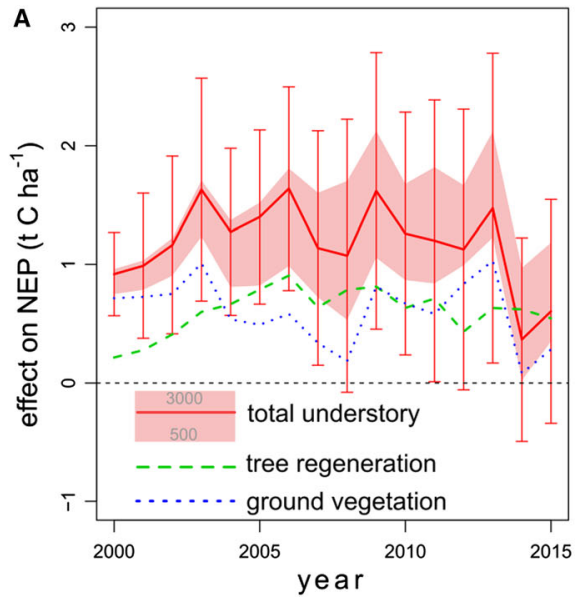

Fig. 5 Regional mean combined ( \pm SD) and single effects of tree regeneration and ground vegetation on annual net ecosystem production (NEP), under disturbance $\left(\mathbf{A}>211 \mathrm{~m}^{3} \mathrm{ha}^{-1}\right.$ stem wood damage between 2005 and 2014) and without disturbance $(\mathbf{B})$. Combined effects were calculated as the difference between scenario $\mathrm{HR}_{500}$ to $\mathrm{HR}_{3000}$ and $\mathrm{NN}$ (mean \pm

increase to the same extent, the NEP contribution of ground vegetation increased relative to tree regeneration in the disturbed forest area. Yet, the number of tree saplings had a strong positive effect on NEP after disturbances. It has to be noted that ground vegetation production was slightly higher in disturbed than in undisturbed areas already in the year 2000 due to a more open tree canopy (i.e. lower tree biomass causing higher ground vegetation coverage and biomass) in disturbed areas.

\section{Discussion}

In our simulations, tree regeneration as well as ground vegetation increased the NEP through photosynthetic $\mathrm{C}$ uptake, particularly after canopy opening due to disturbance. This increase is in line with plot scale studies from other regions (Amiro et al. 2010; Edburg et al. 2011, 2012; Bowler et al. 2012; Don et al. 2012; Williams et al. 2014) as well as chronosequence measurements at Kalkalpen National Park (Zehetgruber et al. 2017). While these previous analyses focused on the plot to stand scale, we here showed that understory vegetation is of considerable relevance for the landscape-scale forest $\mathrm{C}$ balance. We achieved this by using mapped soil and vegetation data, a reconstruction of forest disturbances as drivers of the

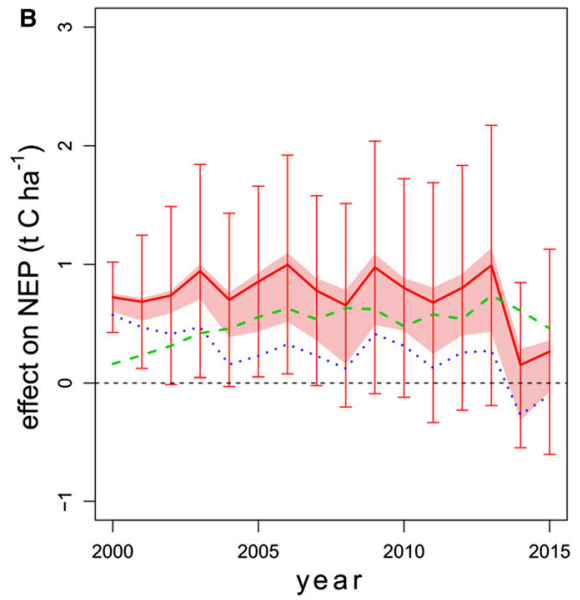

$\mathrm{SD}$ for $\mathrm{HR}_{2500}-\mathrm{NN}$ ). Single effects of tree regeneration (green dashed line) were calculated as the difference between scenario $\mathrm{HR}_{2500}$ and $\mathrm{H}$. Single effects of ground vegetation (blue dotted line) were calculated as the difference between scenario $\mathrm{HR}_{2500}$ and $R_{2500}$

ecosystem model LandscapeDNDC, as well as by considering an environmentally driven development of overstory trees, newly established seedlings, and ground vegetation. Our results show that the cumulative NEP over 15 years was between $16 \%$ and $37 \%$ higher if accounting for the effect of tree regeneration and of ground vegetation compared to simulations without these components. The mean annual contribution of tree regeneration and ground vegetation to NEP ( 0.40 to $0.91 \mathrm{t} \mathrm{C} \mathrm{ha}^{-1}$ year $^{-1}$ ) was in the same order of magnitude as the average annual European (EU-25) forest $\mathrm{C}$ sink $\left(0.75 \mathrm{t} \mathrm{C} \mathrm{ha}^{-1}\right.$ year $\left.^{-1}\right)$ estimated by Luyssaert et al. (2010) for the period 1990 to 2005. Among the two understory components, tree regeneration contributed more strongly to NEP. However, in disturbed areas the effect of ground vegetation to NEP was in the same range. The landscape-scale $\mathrm{C}$ cycle contribution of trees versus ground vegetation was strongly determined by the number of tree saplings prior to disturbance as well as the density-and hence competitive strength-of ground vegetation.

\section{Understory effects on NEP}

The modelled NEP under undisturbed forest conditions (between $2.4 \pm 0.40 \quad(\mathrm{NN}$ scenario) and $3.2 \pm 1.4\left(\mathrm{HR}_{2500}\right.$ scenario) $\mathrm{t} \mathrm{C} \mathrm{ha}^{-1}$ year $\left.^{-1}\right)$ was 
similar to rates typically found in field observations both in the study area (Kobler et al. 2015; Zehetgruber et al. 2017; Kobler et al. 2019) and in other mature temperate forest stands in Europe. As an example, Kowalski et al. (2004) reported a NEP of approx. 1 to $5 \mathrm{t} \mathrm{C} \mathrm{ha}^{-1}$ year $^{-1}$ in mature high forests in Britain, Finland, and France. Etzold et al. (2011) attributed 1.5 and $4.2 \mathrm{t} \mathrm{C} \mathrm{ha}^{-1}$ year $^{-1}$ of NEP to two mountain forests in Switzerland.

While disturbances due to wind and bark beetle began affecting the study area already in the year 2005, substantial loss of growing stock occurred only after 2007 (Fig. 4). Accordingly, annual NEP decreased by $0.7 \pm 0.27 \mathrm{t} \mathrm{C} \mathrm{ha}^{-1}$ year $^{-1}$ after 2007 (NN scenario). The lowest NEP $\left(-4.0 \mathrm{t} \mathrm{C} \mathrm{ha}^{-1}-\right.$ year ${ }^{-1}$ in the $\mathrm{H}$ and $\mathrm{R}_{2500}$ scenarios) occurred during and after the years with peak disturbance (years 2011 and 2012). This finding corresponds well with observations from others, who accounted also for ground vegetation by either using eddy covariance measurements or empirical modelling. Zehetgruber et al. (2017), studying a disturbance chronosequence within our study area, showed that a Norway spruce forest on deep Cambisols became a source of $-5.5 \mathrm{tC} \mathrm{ha}^{-1}$ year $^{-1} 3$ years after stand replacing disturbance. Furthermore, Matthews et al. (2017) observed a seasonal (May to October) NEP of -4.1 and $-1.8 \mathrm{t} \mathrm{C} \mathrm{ha}^{-1}$ year $^{-1}$ three and four years after stand replacing wind throw, respectively. Comparable NEP rates $\left(-3.5 \mathrm{tC} \mathrm{ha}^{-1}\right.$ year $\left.^{-1}\right)$ were observed at a forest site in Germany two years after windthrow from the storm Kyrill (Lindauer et al. 2014), and after clear cutting in four European forests $(-4.3$ to - 1.1 t C ha ${ }^{-1}$ year $^{-1}$, Kowalski et al. (2004)). However, also higher levels of post-disturbance $\mathrm{C}$ loss have been reported, e.g. in a Swedish wind throw area for which Lindroth et al. (2009) estimated a NEP of up to $-10.8 \mathrm{t} \mathrm{C} \mathrm{ha}^{-1}$ year $^{-1}$.

While understory had a positive effect on NEP in most parts of our study area, the magnitude of the effect differed across the landscape and was higher in forests disturbed by wind or bark beetle than in undisturbed forests. Under the NN scenario, i.e. in the absence of tree saplings and ground vegetation, the recovery of $\mathrm{C}$ uptake after disturbance was largely a function of disturbance severity and site productivity, corroborating current knowledge (Anderegg et al. 2016). Also in line with other studies, understory trees surviving a disturbance event or establishing after disturbance lead to a steady recovery of the forest, eventually returning from a $\mathrm{C}$ source to a $\mathrm{C}$ sink (Amiro et al. 2010; Edburg et al. 2012; Williams et al. 2014; Dobor et al. 2018). Resulting from the elevated light, water and nutrient availability after disturbance, an increased growth of ground vegetation, and litter input to the soil, also plays a significant role in this recovery process. Comparable to previous studies (Bowler et al. 2012; Don et al. 2012; Williams et al. 2014; Zehetgruber et al. 2017), we found $35 \%\left(\mathrm{HR}_{500}\right)$ to $67 \%\left(\mathrm{HR}_{3000}\right)$ higher NEP in disturbed areas in contrast to $15\left(\mathrm{HR}_{500}\right)$ to $\left(\mathrm{HR}_{3000}\right) 33 \%$ in undisturbed areas, when considering both tree regeneration and ground vegetation. Notwithstanding the significance of the contribution of the forest understory to NEP in disturbed forests, high severity disturbances were restricted to a relatively small portion of the area in our study region (Thom et al. 2017a). Consequently, interactions between understory dynamics and natural disturbances did not substantially affect the landscape scale $\mathrm{C}$ sink strength in our study area yet having a large potential in the future (Seidl et al. 2014).

Non-woody plants exert competitive effects on tree regeneration (Pröll et al. 2015; Thrippleton et al. 2016), potentially precluding tree establishment after disturbance as shown in e.g. the Yellowstone National Park (Turner et al. 1997). In temperate mountain forest landscapes, these interactions are particularly important because open tree canopies frequently result in a dense herb and grass layer, rapidly increasing production following canopy opening (Ammer 1996). Usually, larger gaps result in higher understory biomass because of higher light availability, more growing space and less root competition (Collins and Pickett 1987; Ritter et al. 2005). In our simulations we have considered overstory regulation on understory growth as well as competition for water and nutrients between understory components. Since herbs and grasses have a higher relative share of active compartments (foliage and fine roots) than trees (that also consist of less respiring wood), respiration per unit biomass and specific turnover rates are higher. Thus, mean NPP:GPP ratios are smaller under scenarios that include ground vegetation ( $\mathrm{H}$ and $\mathrm{HR}$ ). This is in accordance with typical findings from temperate forests (Gilliam 2007). Consequently, the smallest NEP was obtained when only forest ground vegetation but no tree regeneration was considered ( $\mathrm{H}$ scenario). This is in spite of high relative increases in SOC owing 
to the annual litter inputs (highest SOC:NEP ratios were found in the $\mathrm{H}$ scenario) which improves nutrient supply and has been observed to increase carbon assimilation efficiency (Vicca et al. 2012). However, nutrient demand of ground vegetation is also higher so that the overall nutritional state was not significantly changed. Ground vegetation could expand coverage rapidly after overstory disturbance resulting in a more positive immediate effect on GPP than on that of tree regeneration. However, the effect was compensated quickly from the increasing growth of the more efficient tree regeneration that also decreased growth of grass and herbs after a few years in the HR scenarios. Overall, the contributions of tree regeneration and ground vegetation to NEP were similar for the observed period. Considering the whole investigated area, the relatively small portion of severely disturbed areas didn't decrease NEP significantly on a landscape scale, although the effect was considerable looking on disturbed areas alone. Hence, we hypothesize that the balance of positive and negative effects of the forest understory on NEP at the landscape scale will vary with region, disturbance regime as well as the abundance of natural tree regeneration. For temperate mountain forests it seems to be generally important to consider forest ground vegetation in addition to tree regeneration because they are often characterized by open tree canopies resulting in high levels of biomass in non-woody plants (Thrippleton et al. 2016).

\section{Limitations and potential model improvements}

Based on our results showing that forest understory and their interaction substantially affects the forest $\mathrm{C}$ sink, we argue to consider related process also in Earth System Models, corroborating the conclusions in the review of Landuyt et al. (2018). Since forest disturbances disproportionately elevated the contribution of understory to NEP, and forest disturbances are expected to increase in the future due to climate change (Seidl et al. 2014), the consideration of understory processes in models becomes even more important. We here provided an example for a possible implementation in a process-based ecosystem model, but shortcomings as to the representation of certain processes still exist so that an extrapolation to other systems remains to be tested. First, since we compared vital tree regeneration with a hypothetical bare soil scenario, the magnitude of understory effects on NEP simulated here represents an upper bound estimate. However, even though the growth and survival of tree saplings can be limited by various factors, it is very unlikely that trees would fail to regenerate across our entire study area. By studying stem densities between 500 and 3000 saplings per hectare, we quantified the sensitivity of the NEP effect of various regeneration densities, representing realistic ranges. Nevertheless, future studies should incorporate further mechanisms limiting tree regeneration beyond light, water and nutrient availability (e.g. browsing, seed availability), as it has been considered in certain models of forest dynamics (Bugmann 2001; Seidl et al. 2012). LandscapeDNDC doesn't provide a mechanistically driven regeneration model that would consider the appearance of new trees over longer periods and possibly include more species than could be considered in the current approach. This would allow for a more mechanistic representation of vegetation dynamics at the landscape scale (Thrippleton et al. 2016).

Second, we acknowledge that some uncertainty exists regarding the selection of cohorts, since it has been shown that a high aggregation might produce biased results under specific conditions (Wutzler 2008). However, more detail in stand structure increases the dependence on initialization and parameter accuracy and decreases generality of the model results. Therefore, the use of 2-3 cohorts in the few process-oriented ecosystem models that are available is still a common choice (Deckmyn et al. 2008; Jiang et al. 2019).

Third, we have not addressed differences in nonwoody understory dynamics due to different species compositions between forest types. However, Seebacher et al. (2012) showed that varying water and nutrient conditions favour different plant functional types in our study area. It is very likely that the responses of these functional types to environmental perturbations and thus their impact on NEP will differ, likely resulting in variation in their effects on NEP. Exploiting differences in life history strategies when implementing understory dynamics in models is hence an important future direction of research (Landuyt et al. 2018). Third, the total amount of $C$ loss to the atmosphere, apart from being determined by $\mathrm{C}$ uptake in plants, is also driven by altered decomposition dynamics of soil organic matter (Köster et al. 2011; Don et al. 2012). Disturbance can result in warmer and 
wetter soil conditions, enhancing the decomposition of SOM and thus soil respiration (Morehouse et al. 2008; Mayer et al. 2014). These effects can, however, not be broadly extrapolated because partial disturbances are common (Senf et al. 2018), causing only moderate changes in the microclimate and soil respiration (Kobler et al. 2015). Hence, disturbance severity and patch size play an important role for soil respiration in post-disturbance temperate forests (Sommerfeld et al. 2018). Since LandscapeDNDC is not fully able to reflect this heterogeneity in the disturbance regime of temperate forests (Sommerfeld et al. 2018) and instead simulates disturbance effects as a lowered LAI and a homogeneously increased gap fraction, an underestimation of soil warming and thus soil respiration is likely.

\section{Conclusions}

We simulated a positive landscape scale $\mathrm{C}$ sink in all our scenarios for the period 2000 to 2014 corroborating global (Pan et al. 2011) as well as Europe-wide (Luyssaert et al. 2010) assessments showing that temperate forests act as potent $\mathrm{C}$ sinks. However, a net $\mathrm{C}$ sink of the landscape is by no means guaranteed in the future. Among several factors, intensifications of forest disturbances (Seidl et al. 2014) might increase the frequency of periods with a net loss of C (Dobor et al. 2018). We showed that forest ground vegetation strongly compensated disturbance-induced C loss. At the landscape scale, however, tree regeneration was more important for NEP than ground vegetation. Capitalizing from this potential to its full extent will very likely be difficult considering the current degree of damage to tree regeneration by ungulate browsing in Austria (Reimoser and Reimoser 2010; Hangler 2017) and in other European temperate forest regions (Ammer 1996; Motta 1996; Firm et al. 2009; Reimoser and Reimoser 2010; Klopčič et al. 2017). In conclusion, our findings underline the importance of tree regeneration and ground vegetation in the context of the climate change mitigation potential of temperate forest ecosystems.

Acknowledgements Open Access funding provided by Projekt DEAL. This study was funded by the Austrian Climate and Energy Fund ACRP (Grant Agreement Nos. KR14AC7K11960, CentForCSink) and the European Union's Horizon 2020 research and innovation programme (Grant
Agreement No. 641762, ECOPOTENTIAL). R. Seidl acknowledges support from the Austrian Science Fund FWF through START Grant Y895-B25. We are grateful to the National Park Kalkalpen, the Austrian Federal Forests, and LTER Zöbelboden for data and local support.

Open Access This article is licensed under a Creative Commons Attribution 4.0 International License, which permits use, sharing, adaptation, distribution and reproduction in any medium or format, as long as you give appropriate credit to the original author(s) and the source, provide a link to the Creative Commons licence, and indicate if changes were made. The images or other third party material in this article are included in the article's Creative Commons licence, unless indicated otherwise in a credit line to the material. If material is not included in the article's Creative Commons licence and your intended use is not permitted by statutory regulation or exceeds the permitted use, you will need to obtain permission directly from the copyright holder. To view a copy of this licence, visit http://creativecommons.org/licenses/by/4.0/.

\section{References}

Amiro BD, Barr AG, Barr JG, Black TA, Bracho R, Brown M, Chen J, Clark KL, Davis KJ, Desai AR, Dore S, Engel V, Fuentes JD, Goldstein AH, Goulden ML, Kolb TE, Lavigne MB, Law BE, Margolis HA, Martin T, McCaughey JH, Misson L, Montes-Helu M, Noormets A, Randerson JT, Starr G, Xiao J (2010) Ecosystem carbon dioxide fluxes after disturbance in forests of North America. J Geophys Res Biogeosci 115(G4):G00K02

Ammer C (1996) Impact of ungulates on structure and dynamics of natural regeneration of mixed mountain forests in the Bavarian Alps. For Ecol Manag 88(1):43-53

Anderegg WRL, Martinez-Vilalta J, Cailleret M, Camarero JJ, Ewers BE, Galbraith D, Gessler A, Grote R, Huang C-y, Levick SR, Powell TL, Rowland L, Sánchez-Salguero R, Trotsiuk V (2016) When a tree dies in the forest: scaling climate-driven tree mortality to ecosystem water and carbon fluxes. Ecosystems 19(6): 1133-1147

Bonan GB, Doney SC (2018) Climate, ecosystems, and planetary futures: the challenge to predict life in Earth system models. Science 359(6375):eaam8328

Bossel H (1996) TREEDYN3 forest simulation model. Ecol. Modelling 90:187-227

Bowler R, Fredeen AL, Brown M, Andrew Black T (2012) Residual vegetation importance to net $\mathrm{CO}_{2}$ uptake in pinedominated stands following mountain pine beetle attack in British Columbia, Canada. For Ecol Manag 269:82-91

Brown M, Black TA, Nesic Z, Foord VN, Spittlehouse DL, Fredeen AL, Grant NJ, Burton PJ, Trofymow JA (2010) Impact of mountain pine beetle on the net ecosystem production of lodgepole pine stands in British Columbia. Agric For Meteorol 150(2):254-264

Bugmann H (2001) A review of forest gap models. Clim Chang 51(3):259-305

Ciais P, Reichstein M, Viovy N, Granier A, Ogée J, Allard V, Aubinet M, Buchmann N, Bernhofer C, Carrara A, 
Chevallier F, De Noblet N, Friend AD, Friedlingstein P, Grünwald T, Heinesch B, Keronen P, Knohl A, Krinner G, Loustau D, Manca G, Matteucci G, Miglietta F, Ourcival JM, Papale D, Pilegaard K, Rambal S, Seufert G, Soussana JF, M. J. Sanz S, E-D, Vesala T, Valentini R (2005) Europe-wide reduction in primary productivity caused by the heat and drought in 2003. Nature 437:529-533

Collins BS, Pickett STA (1987) Influence of canopy opening on the environment and herb layer in a northern hardwoods forest. Vegetatio 70(1):3-10

Deckmyn G, Verbeeck H, Op de Beeck M, Vansteenkiste D, Steppe K, Ceulemans R (2008) ANAFORE: a stand-scale process-based forest model that includes wood tissue development and labile carbon storage in trees. Ecol Model 215:345-368

Diaci J, Pisek R, Boncina A (2005) Regeneration in experimental gaps of subalpine Picea abies forest in the Slovenian Alps. Eur J For Res 124(1):29-36

Dirnböck T, Kobler J, Kraus D, Grote R, Kiese R (2016) Impacts of management and climate change on nitrate leaching in a forested karst area. J Environ Manag 165:243-252

Dobor L, Hlásny T, Rammer W, Barka I, Trombik J, Pavlenda P, Šebeò V, Štìpánek P, Seidl R (2018) Post-disturbance recovery of forest carbon in a temperate forest landscape under climate change. Agric For Meteorol 263:308-322

Don A, Bärwolff M, Kalbitz K, Andruschkewitsch R, Jungkunst HF, Schulze E-D (2012) No rapid soil carbon loss after a windthrow event in the High Tatra. For Ecol Manag 276:239-246

Edburg SL, Hicke JA, Brooks PD, Pendall EG, Ewers BE, Norton U, Gochis D, Gutmann ED, Meddens AJH (2012) Cascading impacts of bark beetle-caused tree mortality on coupled biogeophysical and biogeochemical processes. Front Ecol Environ 10(8):416-424

Edburg SL, Hicke JA, Lawrence DM, Thornton PE (2011) Simulating coupled carbon and nitrogen dynamics following mountain pine beetle outbreaks in the western United States. J Geophys Res 116(G4):G04033

Etzold S, Ruehr N, Zweifel R, Dobbertin M, Zingg A, Pluess P, Häsler R, Eugster W, Buchmann N (2011) The carbon balance of two contrasting mountain forest ecosystems in Switzerland: similar annual trends, but seasonal differences. Ecosystems 14(8):1289-1309

Firm D, Nagel TA, Diaci J (2009) Disturbance history and dynamics of an old-growth mixed species mountain forest in the Slovenian Alps. For Ecol Manag 257(9):1893-1901

Flato G, Marotzke J, Abiodun B, Braconnot P, Chou SC, Collins W, Cox P, Driouech F, Emori S, Eyring V, Forest C, Gleckler P, Guilyardi E, Jakob C, Kattsov V, Reason C, Rummukainen M (2013) Evaluation of climate models. In: Stocker TF, Qin D, Plattner G-K, Tignor M, Allen SK, Boschung J, Nauels A, Xia Y, Bex V, Midgley PM (eds) Climate Change 2013: The Physical Science Basis. Contribution of Working Group I to the Fifth Assessment Report of the Intergovernmental Panel on Climate Change. Cambridge University Press, Cambridge, United Kingdom and New York, NY, USA, pp 741-866

Gilliam FS (2007) The ecological significance of the herbaceous layer in temperate forest ecosystems. Bioscience 57(10):845-858
Gregow H, Laaksonen A, Alper ME (2017) Increasing large scale windstorm damage in Western, Central and Northern European forests, 1951-2010. Sci Rep 7:46397

Grote R (2003) Estimation of crown radii and crown projection area from stem size and tree position. Ann For Sci 60:393-402

Grote R (2007) Sensitivity of volatile monoterpene emission to changes in canopy structure: a model-based exercise with a process-based emission model. New Phytol 173(3):550-561

Grote R, Kiese R, Grünwald T, Ourcival J-M, Granier A (2011a) Modelling forest carbon balances considering tree mortality and removal. Agric For Meteorol 151(2):179-190

Grote R, Korhonen J, Mammarella I (2011b) Challenges for evaluating process-based models of gas exchange. For Syst 20(3):389-406

Grote R, Lehmann E, Brümmer C, Brüggemann N, Szarzynski J, Kunstmann H (2009) Modelling and observation of biosphere-atmosphere interactions in natural savannah in Burkina Faso, West Africa. Phys Chem Earth Parts A/B/C 34:251-260

Gupta HV, Kling H, Yilmaz KK, Martinez GF (2009) Decomposition of the mean squared error and NSE performance criteria: implications for improving hydrological modelling. J Hydrol 377(1-2):80-91

Haas E, Klatt S, Fröhlich A, Kraft P, Werner C, Kiese R, Grote R, Breuer L, Butterbach-Bahl K (2013) LandscapeDNDC: a process model for simulation of biosphere-atmospherehydrosphere exchange processes at site and regional scale. Landsc Ecol 28(4):615-636

Hangler J (2017) Wildschadensbericht 2016. Retrieved from Vienna, Austria: https://www.bmnt.gv.at/forst/oesterreichwald/waldzustand/wildschadensbericht2016.html

Helm N, Essl F, Mirtl M, Dirnböck T (2017) Multiple environmental changes drive forest floor vegetation in a temperate mountain forest. Ecol Evol 7(7):2155-2168

Jasser C, Diwold G (2014) Baumartenwahl im Gebirge, Empfehlungen für das oberösterreichische Kalk-und Flyschgebiet. Retrieved from Linz, Austria: https://www. land-oberoesterreich.gv.at/files/publikationen/Broschuere_\% 20Baumartenwahl_im\%20_Gebirge_2015.pdf

Jiang Y, Kim JB, Trugman AT, Kim Y, Still CJ (2019) Linking tree physiological constraints with predictions of carbon and water fluxes at an old-growth coniferous forest. Ecosphere 10:e02692

Jost G, Dirnböck T, Grabner M-T, Mirtl M (2011) Nitrogen leaching of two forest ecosystems in a Karst Watershed. Water Air Soil Pollut 218(1):633-649

Kiese R, Heinzeller C, Werner C, Wochele S, Grote R, Butterbach-Bahl K (2011) Quantification of nitrate leaching from German forest ecosystems by use of a process oriented biogeochemical model. Environ Pollut 159(11):3204-3214

Klopčič M, Mina M, Bugmann H, Bončina A (2017) The prospects of silver fir (Abies alba Mill.) and Norway spruce (Picea abies (L.) Karst) in mixed mountain forests under various management strategies, climate change and high browsing pressure. Eur J For Res 136(5):1071-1090

Kobler J (2004) Risikokarten als Planungsgrundlage für Flächenbewirtschaftung und Tourismuslenkung im 
Nationalpark Kalkalpen Oberösterreich. University of Vienna, Vienna

Kobler J, Jandl R, Dirnböck T, Mirtl M, Schindlbacher A (2015) Effects of stand patchiness due to windthrow and bark beetle abatement measures on soil $\mathrm{CO}_{2}$ efflux and net ecosystem productivity of a managed temperate mountain forest. Eur J For Res 134:683-692

Kobler J, Zehetgruber B, Dirnböck T, Jandl R, Mirtl M, Schindlbacher A (2019) Effects of aspect and altitude on carbon cycling processes in a temperate mountain forest catchment. Landsc Ecol 34:325-340

Köster K, Püttsepp Ü, Pumpanen J (2011) Comparison of soil $\mathrm{CO}_{2}$ flux between uncleared and cleared windthrow areas in Estonia and Latvia. For Ecol Manag 262(2):65-70

Kowalski AS, Loustau D, Berbigier P, Manca G, Tedeschi V, Borghetti M, Valentini R, Kolari P, Berninger F, Rannik Ü (2004) Paired comparisons of carbon exchange between undisturbed and regenerating stands in four managed forests in Europe. Glob Chang Biol 10(10):1707-1723

Kraus D, Weller S, Klatt S, Haas E, Wassmann R, Kiese R, Butterbach-Bahl K (2015) A new LandscapeDNDC biogeochemical module to predict $\mathrm{CH}_{4}$ and $\mathrm{N}_{2} \mathrm{O}$ emissions from lowland rice and upland cropping systems. Plant Soil 386(1-2):125-149

Kupferschmid AD, Bugmann H (2005) Effect of microsites, $\operatorname{logs}$ and ungulate browsing on Picea abies regeneration in a mountain forest. For Ecol Manag 205:251-265

Landuyt D, Perring MP, Seidl R, Taubert F, Verbeeck H, Verheyen K (2018) Modelling understorey dynamics in temperate forests under global change-challenges and perspectives. Perspect Plant Ecol Evol Syst 31:44-54

Lindauer M, Schmid HP, Grote R, Mauder M, Steinbrecher R, Wolpert B (2014) Net ecosystem exchange over a noncleared wind-throw-disturbed upland spruce forest-measurements and simulations. Agric For Meteorol 197:219-234

Lindroth A, Lagergren F, Grelle A, Klemedtsson L, Langvall OLA, Weslien PER, Tuulik J (2009) Storms can cause Europe-wide reduction in forest carbon sink. Glob Chang Biol 15(2):346-355

Lovett G, Cole J, Pace M (2006) Is net ecosystem production equal to ecosystem carbon accumulation? Ecosystems 9(1):152-155

Luyssaert S, Ciais P, Piao SL, Schulze ED, Jung M, Zaehle S, Schelhaas MJ, Reichstein M, Churkina G, Papale D, Abril G, Beer C, Grace J, Loustau D, Matteucci G, Magnani F, Nabuurs GJ, Verbeeck H, Sulkava M, Van Der Werf GR, Janssens IA, members of the C-IST (2010) The European carbon balance. Part 3: forests. Glob Chang Biol 16(5):1429-1450

Mathys A, Black TA, Nesic Z, Nishio G, Brown M, Spittlehouse DL, Fredeen AL, Bowler R, Jassal RS, Grant NJ, Burton PJ, Trofymow JA, Meyer G (2013) Carbon balance of a partially harvested mixed conifer forest following mountain pine beetle attack and its comparison to a clear-cut. Biogeosciences 10(8):5451-5463

Matthews B, Mayer M, Katzensteiner K, Godbold DL, Schume H (2017) Turbulent energy and carbon dioxide exchange along an early-successional windthrow chronosequence in the European Alps. Agric For Meteorol 232:576-594
Mayer M, Matthews B, Schindlbacher A, Katzensteiner K (2014) Soil $\mathrm{CO}_{2}$ efflux from mountainous windthrow areas: dynamics over 12 years post-disturbance. Biogeosciences 11(21):6081-6093

Molina-Herrera S, Grote R, Santabárbara-Ruiz I, Kraus D, Klatt S, Haas E, Kiese R, Butterbach-Bahl K (2015) Simulation of $\mathrm{CO}_{2}$ fluxes in European forest ecosystems with the coupled soil-vegetation process model "LandscapeDNDC". Forests 6(6):1779

Morehouse K, Johns T, Kaye J, Kaye M (2008) Carbon and nitrogen cycling immediately following bark beetle outbreaks in southwestern ponderosa pine forests. For Ecol Manage 255(7):2698-2708

Motta R (1996) Impact of wild ungulates on forest regeneration and tree composition of mountain forests in the Western Italian Alps. For Ecol Manag 88(1):93-98

Nilsson M-C, Wardle DA (2005) Understory vegetation as a forest ecosystem driver: evidence from the northern Swedish boreal forest. Front Ecol Environ 3(8):421-428

Nopp-Mayr U, Kempter I, Muralt G, Gratzer G (2012) Seed survival on experimental dishes in a central European oldgrowth mixed-species forest-effects of predator guilds, tree masting and small mammal population dynamics. Oikos 121(3):337-346

Pan Y, Birdsey RA, Fang J, Houghton R, Kauppi PE, Kurz WA, Phillips OL, Shvidenko A, Lewis SL, Canadell JG, Ciais P, Jackson RB, Pacala SW, McGuire AD, Piao S, Rautiainen A, Sitch S, Hayes D (2011) A large and persistent carbon sink in the world's forests. Science 333(6045):988-993

Pröll G, Darabant A, Gratzer G, Katzensteiner K (2015) Unfavourable microsites, competing vegetation and browsing restrict post-disturbance tree regeneration on extreme sites in the Northern Calcareous Alps. Eur J For Res 134(2):293-308

Reimoser F, Gossow H (1996) Impact of ungulates on forest vegetation and its dependence on the silvicultural system. For Ecol Manag 88(1):107-119

Reimoser F, Reimoser S (2010) Ungulates and their management in Austria. In: Apollonio M, Andersen A, Putman P (eds) European ungulates and their management in the 21th century. Cambridge University Press, Cambridge, pp 338-356

Ritter E, Dalsgaard L, Einhorn KS (2005) Light, temperature and soil moisture regimes following gap formation in a semi-natural beech-dominated forest in Denmark. For Ecol Manag 206(1-3):15-33

Seebacher D, Dirnböck T, Dullinger S, Karrer G (2012) Smallscale variation of plant traits in a temperate forest understorey in relation to environmental conditions and disturbance. Stapfia 97:153-168

Seidl R, Rammer W (2017) Climate change amplifies the interactions between wind and bark beetle disturbances in forest landscapes. Landsc Ecol 32(7):1485-1498

Seidl R, Rammer W, Scheller RM, Spies TA (2012) An individual-based process model to simulate landscape-scale forest ecosystem dynamics. Ecol Model 231:87-100

Seidl R, Schelhaas M-J, Rammer W, Verkerk PJ (2014) Increasing forest disturbances in Europe and their impact on carbon storage. Nat Clim Chang 4:806-810

Senf C, Pflugmacher D, Zhiqiang Y, Sebald J, Knorn J, Neumann M, Hostert P, Seidl R (2018) Canopy mortality has 
doubled in Europe's temperate forests over the last three decades. Nat Commun 9(1):4978

Shinozaki K, Yoda K (1964) A quantitative analysis of plant form-the pipe model theory. I. Basic analyses. Jpn J Ecol 14:97-105

Sommerfeld A, Senf C, Buma B, D'Amato AW, Després T, Díaz-Hormazábal I, Fraver S, Frelich LE, Gutiérrez ÁG, Hart SJ, Harvey BJ, He HS, Hlásny T, Holz A, Kitzberger T, Kulakowski D, Lindenmayer D, Mori AS, Müller J, Paritsis J, Perry GLW, Stephens SL, Svoboda M, Turner MG, Veblen TT, Seidl R (2018) Patterns and drivers of recent disturbances across the temperate forest biome. Nat Commun 9(1):4355

Steffen W, Rockström J, Richardson K, Lenton TM, Folke C, Liverman D, Summerhayes CP, Barnosky AD, Cornell SE, Crucifix M, Donges JF, Fetzer I, Lade SJ, Scheffer M, Winkelmann R, Schellnhuber HJ (2018) Trajectories of the earth system in the Anthropocene. Proc Natl Acad Sci USA 115(33):8252-8259

Thom D, Rammer W, Dirnböck T, Müller J, Kobler J, Katzensteiner K, Helm N, Seidl R (2017a) The impacts of climate change and disturbance on spatio-temporal trajectories of biodiversity in a temperate forest landscape. J Appl Ecol 54(1):28-38

Thom D, Rammer W, Seidl R (2017b) The impact of future forest dynamics on climate: interactive effects of changing vegetation and disturbance regimes. Ecol Monogr 87(4):665-684

Thrippleton T, Bugmann H, Kramer-Priewasser K, Snell RS (2016) Herbaceous understorey: an overlooked player in forest landscape dynamics? Ecosystems 19(7):1240-1254
Turner MG, Dale VH, Everham IIIEH (1997) Fires, hurricanes, and volcanoes: comparing large disturbances. Bioscience 47(11):758-768

Vicca S, Luyssaert S, Peñuelas J, Campioli M, Chapin FS, Ciais P, Heinemeyer A, Högberg P, Kutsch WL, Law BE, Malhi Y, Papale D, Piao SL, Reichstein M, Schulze ED, Janssens IA (2012) Fertile forests produce biomass more efficiently. Ecol Lett 15:520-526

Williams CA, Vanderhoof MK, Khomik M, Ghimire B (2014) Post-clearcut dynamics of carbon, water and energy exchanges in a midlatitude temperate, deciduous broadleaf forest environment. Glob Chang Biol 20(3):992-1007

WMO (2015) WMO statement on the status of the global climate in 2014. https://library.wmo.int/pmb_ged/wmo_ 1152_en.pdf

Wutzler T (2008) Effect of the aggregation of multi-cohort mixed stands on modeling forest ecosystem carbon stocks. Silva Fenn 42:53-553

Zambrano-Bigiarini M (2017) Goodness-of-fit functions for comparison of simulated and observed hydrological time series, R package version 0.3-10. http://hzambran.github. io/hydroGOF/

Zehetgruber B, Kobler J, Dirnböck T, Jandl R, Seidl R, Schindlbacher A (2017) Intensive ground vegetation growth mitigates the carbon loss after forest disturbance. Plant Soil 420(1):239-252

Publisher's Note Springer Nature remains neutral with regard to jurisdictional claims in published maps and institutional affiliations. 